\title{
The Education Minister and the disqualified teachers
}

\author{
by Graham Ritchie
}

\begin{abstract}
This overview of the UK legal and administrative framework for the disqualification of teachers and child care workers asks whether the system is compliant with the European Convention on Human Rights.
\end{abstract}

$\mathrm{T}$ he media coverage at the beginning of 2006 directed to the Secretary of State for Education and Skills, Ruth Kelly, and her authorisation of the employment, as teachers, of some persons, who appear on the Department of Education List (List 99), draws attention to a number of employment, jurisprudential, and constitutional issues. People who appear on List 99 are considered to be a risk to children.

The employment, jurisprudential, and constitutional issues that arise are a consequence of the Human Rights Act 1998 which introduced the European Convention on Human Rights (ECHR) into UK domestic law. Recent political excitement has been caused by the press discovering that some teachers on List 99 have been authorised to continue to work in schools. Once this has died down, the issues remain unresolved.

A survey of the current administrative and legal structure that exists in the UK and Europe generally for the documenting of persons considered to be a risk to children is a first step in the consideration of these issues. It is also timely to consider the compatability of the current UK administrative and legal structure with the European Convention on Human Rights. This article describes the UK administrative and legal structure for documenting persons considered to be a risk to children and then assess that structure in the light of the supranational law embodied in Article 6 of the ECHR.

\section{CHILD PROTECTION AND THE ECHR}

In 2001 the European Commission Directorate-General for Justice and Home Affairs commissioned a Study on Disqualification from Working with Children within the EU (Child Study JA1/B3/2001, G Ritchie). The purpose of this study was to provide information about the legal frameworks in individual EU Member States for the disqualification of people from working with children if they had committed offences against children. The original assumption of the EU request for such a study was that a person would only be disqualified from working with children if they had first been convicted of an offence against a child or children.
This assumption holds good for most Member States of the European Union but the UK has traditionally adopted a different approach. The UK system works on the basis that access to employment, which brings persons into contact with children, should be restricted or denied even in those situations where there have been no criminal charges and no court adjudication of the alleged misbehaviour. People can even be denied the right to work with or near children on the basis of unconfirmed suspicion.

\section{SITUATION IN THE EUROPEAN UNION AND ENGLAND AND WALES}

There have been a number of EU studies about the problem of people who are a risk to children being denied access to children. An early study is that prepared by the UK National Society for the Protection of Children pursuant to the Daphne Initiative of the European Commission - The Collection and Use of Personal Information on Child Sex Offenders(CUPISCO). The Executive Summary of the CUPISCO report states:
“..........In the European Union of the late 1990's there is a need to consider pre-employment screening by means of a criminal record check on an inter-national basis. As frontiers and other barriers to employment across the E.U. have been purposefully dismantled, people are more internationally mobile for purposes of employment-and potentially for the purposes of criminal activity.
The exchange of personal information (criminal records) between Member States for the purposes of screening would-be child care workers provides a new dimension to the work of the custodians of the databases-the police and child protection agencies....."

Prior to April 1, 2002, when the UK Criminal Records Bureau was established to replace the Police National Computer, the following arrangements were in place:

1. A Department of Health Consultancy List was created. This is a list of persons considered to be unsuitable to work with children within the health sector. It had not been clear who could have access to this list, and how 
anybody included in the list could appeal against inclusion of their name on the list prior to 2000 when the Care Standards Tribunal, was set up pursuant to the Protection of Children Act (POCA) 1999.

2. The Department of Education List (List 99) which includes those unsuitable to teach and to hold other posts in schools.

3. The Sex Offenders Act of 1997 required sex offenders convicted under schedule 1 of the Act to register their names and addresses with the police.

4. Sex offenders orders, introduced under the Crime and Disorder Act 2000, apply to offenders who have at any time been convicted or cautioned for a sexual offence if they are considered to be a continuing risk.

5. Extended sentence provisions in the Crime and Disorder Act 2000 gave courts powers to pass extended sentences on sex and violence offenders. This means sex offenders may be subject to an extended period of post release supervision for up to 10 years.

6. The Criminal Justice and Courts Services Act 2000 provides:

(a) the courts have the power to disqualify people responsible for the commission of a serious offence against a child from working with children by issuing a disqualification order.

(b) harsh criminal sanctions can be imposed on a person who is in breach of a court disqualification order. Criminal sanctions are also available for breaches of disqualification from working with children by virtue of inclusion in the POCA List or List 99, or any other scheme for the disqualification of persons from working with children.

7. Regulation of Investigatory Powers Act 2001 makes it easier for the Police to monitor the activities of paedophiles on the internet.

8. The Protection of Children Act 1999 created a "Protection of Children Act List", (POCA List), and provided a right of appeal to the Care Standards Tribunal for those persons included on the list. This Act required for the first time potential employers in the child care, education, etc sectors to check prospective employees against the POCA list, The Department of Health Consultancy List, the Department of Education List (List 99).

9. The Police Act 1997, as amended at sections 113 and 115 by the Child Protection Act 1999 established the Criminal Records Bureau, (CRB), which has been operational since 1 April 2002. Criminal convictions had previously been stored on the Police National Computer.

10. Employers must check prospective employees with the $\mathrm{CRB}$ for the following activities: (i) child care workers

(ii) workers in specified educational organizations who are responsible for child care

(iii) teachers

(iv) workers in any post which brings the holder into regular contact with children under the age of 19

(v) or other relevant position

The entries can include convictions, or cautions in the case of child workers. (Cautions are not normally included in $\mathrm{CRB}$ records other than for child workers). Child care workers are an exception within the provisions of the Freedom of Information Act 2000.

\section{CRIMINAL RECORDS IN ENGLAND AND WALES}

In England and Wales, criminal convictions are recorded at both national and local level.

It should be noted that in April 2006 the National Criminal Intelligence Service and the National Crime Squad merged with the newly formed Serious Organised Crime Agency (SOCA).

In addition to the Criminal Records Bureau, which maintains a national data base, police forces maintain local records of convictions and lesser reprimands locally. The National Criminal Intelligence Service is also required under section 2(2) of the Police Act 1997:

(a) to gather, store and analyse information in order to provide criminal intelligence;

(b) to provide criminal intelligence to police forces in Great Britain. The Northern Ireland Police Service, the National Crime Squad and other law enforcement agencies, and

(c) to act in support of such police forces............ and other law enforcement agencies carrying out their criminal intelligence activities.

An official record of convictions is defined by section 9(1) of the Rehabilitation of Offenders Act 1974 as:

"a record kept for the purposes of its functions by any court, police force, government department, local or other public authority in Great Britain, or a record kept, in Great Britain, or elsewhere, for the purposes of any of Her Majesty's forces, being in either case a record containing information about persons convicted of offences."

\section{ACCESS TO CRIMINAL RECORDS}

Access to and, use of, criminal records are primarily for the purposes of criminal intelligence by the police, by the courts for sentencing purposes, and for the assessment of fitness for professional employment in a number of sectors including education and child care. 
Part V of the Police Act 1997 makes provision for this. The Criminal Records Bureau issues three types of certificate relating to criminal records.

1. A criminal conviction certificate

2. A criminal record certificate

3. An enhanced criminal record certificate

These three types of certificate cover three levels of disclosure:

(a) Basic disclosures, which are available to those who are expected to voluntarily present a record of convictions to prospective employers or for other purposes.

(b) Standard disclosures, which are available for those whose duties include working with children in a regulated position.

(c) Enhanced disclosures, which are available for those applying for positions which involve the regular care for, training of, supervision of, or sole charge of persons under the age of 18 .

An enhanced criminal record certificate is available in respect of enquiries into an applicant's suitability for a paid or an unpaid position that involves the person regularly caring for, or training, or supervising children and young people under 18 years old; for appointments to the judiciary, and also for certain "statutory licensing purposes", and Crown appointments.

The enhanced criminal record certificate gives details of any relevant convictions or cautions held on central records, as well as any information held by any chief officer of any police force that may be relevant and ought to be included on the certificate. This includes spent and unspent convictions and non-convictions, and cautions issued by police forces. An enhanced criminal record contains information on List 99, the POCA list (see below), The Department of Health Consultancy List, and lists pursuant to the Sex Offenders Act 1997, Crime and Disorder Act 2000, and other statutes.

\section{POCA LIST}

The Protection of Children Act 1999 establishes a protection of children list of people considered to be unsuitable to work with children (The POCA list). Child organisations must, and other organizations may, refer names to the Secretary of State for inclusion in the POCA list to be considered. The relevant circumstances are:

(a) where an organization has dismissed the individual on the grounds of misconduct, whether or not in the course of their employment, which harmed a child, or placed a child at risk.

(b) Where an individual has resigned or retired in circumstances such that the organization would have dismissed them, or would have considered dismissing them on such grounds if they had not resigned or retired.

(c) Where an organization has, on such grounds, transferred the individual to a position within the organisation which is not a child care position.

(d) Where an organisation has, on such grounds, suspended the individual or provisionally transferred them to a position which is not a child care position but has yet decided whether to dismiss him or to confirm the transfer.

(e) Where an organisation has dismissed the individual, who has resigned, retired or has transferred to a position within the organisation which is not a child care position and where information not available to the organisation at the time has since become available.

(f) Where on the basis of that information the organisation has formed the opinion that, had the information been available at the time and if, where applicable, the individual had not resigned or retired, the organisation would have considered dismissing them on the grounds of misconduct which harmed a child or placed a child at risk of harm.

(g) Where a child care worker has been suspended, dismissed or resigned after having been charged with offences against children and who are awaiting the outcome of criminal investigation or trial.

The Secretary of State must:

(a) Examine the quality of information submitted with a referral to decide whether to proceed with the case or not to proceed with the case if the case is not suitable for inclusion.

(b) Invite observations from the individual and the relevant organisation to consider whether to proceed with a decision to provisionally include the name of an individual in the POCA list.

(c) Confirm the provisional inclusion of a name in the POCA list with the relevant organisation and immediately inform the individual by letter of his provisional inclusion.

(d) Provide the individual with full details of the information submitted by the referring organisation in the event that the individual makes a representation to the Secretary of State after having been informed of the provisional inclusion of his name in the POCA list.

(e) Retain an individual's name on the POCA list after satisfying himself that the referring organisation had reasonable grounds for a referral to the list.

(f) Form an opinion about confirming the name on the POCA list when the organisation has dismissed the individual or has confirmed his transfer where an individual has been provisionally included in the list whilst suspended or provisionally transferred to a 
position within the organisation which is not a child care position.

\section{EFFECT OF INCLUSION IN THE LIST}

Persons provisionally included in either the POCA list or list 99 may not be employed in a child care position within a child care organisation.

Other organisations should consider the fact that an individual is provisionally included in the POCA List when considering his appointment to a post which involves contact with children. The Secretary of State has discretionary powers to delete names from the POCA List in limited circumstances, for instance where a conviction has been quashed or on appeal or where malicious referral is uncovered following the production of new evidence, without consulting with the Care Standards Tribunal.

Persons who have been provisionally included in the POCA list for more than nine months may, with leave of the Care Standards Tribunal, have the issue of their inclusion on the list determined by the Care Standards Tribunal instead of the Secretary of State.

If an individual is the subject of allegations and is involved in civil or criminal proceedings resulting from those allegations an application to the Care Standards Tribunal cannot be made until six months after the completion of those proceedings.

The Protection of Children Act 1999 amends the Education Reform Act 1988 and sets out the following grounds for inclusion in list 99:

(a) medical reasons;

(b) misconduct;

(c) not being fit and proper to work as a teacher;

(d) an individual is included in the POCA list;

(e) in respect of employment and educational grounds these are adequate to bar a teacher from working with children.

\section{WHY UK IS "ODD ONE OUT" IN EUROPE}

The approach of EU countries (with the exception of England, Wales, Scotland, Northern Ireland, and the Republic Ireland) is that there should be no disqualification penalty without court adjudication and conviction for a relevant offence. This is universally the result of the jurisprudence of the individual civil code countries of the European Union. The exceptions are the common law countries stated above (and Scotland has some aspects of a civil code jurisdiction).

It can be argued that this policy is an ill fit with Article 6 ECHR (1). Disqualification, as with any other civil or criminal penalty against a person, is assumed to be a sanction which can only be imposed after the person to be sanctioned has had the right of a fair trial. Article 6 ECHR is there to ensure that the objective truth about a person's behaviour is established by an independent court before any sanction is imposed.

After the destruction of human values in the second world war, mainland European countries have displayed a manifest aversion to the non-judicial or non court adjudicated actions of the state, where such state action is based on informants and black lists. Article 6 is a bastion against the future destruction of personal integrity and the right to life and freedom of individual people by arbitrary state power.

\section{ARTICLE 6 (RIGHT TO A FAIR TRIAL)}

Article 6 states:

1. In the determination of his civil rights and obligations or of any criminal charge against him, everyone is entitled to a fair and public hearing within a reasonable time by an independent and impartial tribunal established by law. Judgment shall be pronounced publicly but the press and public may be excluded from all or part of the trial in the interests of morals, public order or national security in a democratic society, where the interests of juveniles or the protection of the private life of the parties so require, or to the extent strictly necessary in the opinion of the court in special circumstances where publicity would prejudice the interests of justice.

2. Everyone charged with a criminal offence shall be presumed innocent until proved guilty according to law.

3. Everyone charged with a criminal offence has the following minimum rights:

(a) to be informed promptly, in a language which he understands and in detail, of the nature and cause of the accusation against him;

(b) to have adequate time and facilities for the preparation of his defence;

(c) to defend himself in person or through legal assistance of his own choosing or, if he has not sufficient means to pay for legal assistance, to be given it free when the interests of justice so require;

(d) to examine or have examined witnesses against him and to obtain the attendance and examination of witnesses on his behalf under the same conditions as witnesses against him;

(e) to have the free assistance of an interpreter if he cannot understand or speak the language used in court.

This sublime principle is seemingly qualified in UK and Eire. There is no detectable jurisprudential explanation of that, although a thread of reasoning and constitutional assumptions can be detected in individual case law. The usual common law approach of these jurisdictions - which includes elements of expedience, empiricism, and utility as 
well as legal theory - has resulted in this different and evolutionary approach to the rights of persons disqualified from working with children. Layered on top of that common law approach has been recent parliamentary legislation in response to the need to provide a comprehensive and effective legal structure for the protection of children. This legislation, in parts, is characterised by being a short term political response.

The UK legal approach is to start from the opposite end to that of a civil code country. The UK approach is to respond to a problem by identifying the desirable political/pragmatic "good of society" effect and then to construct a legal theoretical justification for that end result. The civil code approach is to identify the governing theoretical legal principle and then see how this principle determines a practical legal outcome. The UK legal approach is, in effect, to allow the use of non adjudicated allegation to be used to limit a person's freedom of employment, or access to children. In the UK this type of allegation/information can be included in a person's criminal record, held at the Criminal Record Bureau.

The common law approach to proportionality is to see it as a reasonable balance between the rights of an individual and society at large. The desirable and practical outcome of a situation is identified and defined, and then "human rights" can be balanced within that context. The civil code approach is to identify the governing "human rights" principle and then to apply that principle to the facts in question. The process is different to the "reasonable balance" test as assessed by common law courts, being a methodical assessment of proportionality in application of the facts of a situation to a human rights principle.

The ECHR has a hierarchy of rights. For example, the right to life or the right to a fair trial is immutable. The right to privacy is capable of qualification after application of the "reasonable balance" or the "proportionality" tests.

All arguments of "reasonable balance" or "proportionality" are unavailable for qualification of the "immutable rights" or "principles". Nevertheless, the UK has taken a robust line and inclines toward the "public good" as a principle which overrides basic derivative issues of article 6 ECHR. In the case of children the "paramount principle" which prioritises the interests of children above the interests of adults or institutions as adopted in national law, and the United Nations Convention on the Rights of the Child 1989 can be argued to override the human rights of adults working with children.

The UK legal process has not been noted for legal theorisation in an abstract form. The common law process has been a reactive type of legal rationalisation of practical cases brought before the courts. It should be noted that:

1. This approach has served the UK reasonably well. Although it would never be admitted there is such a thing as "judge made law" rather than "judge interpreted Law". Developmental stages in the law are usually a response to changes in society.

2. The UK common law legal system has gradually become part of a European civil code system because the UK has been a member of the European Union since 1971. This has had an increasing impact on the constitution of the UK - something always feared by opponents of integration and denied by its proponents.

3. The pre- EU system was that Parliament was the supreme law maker. The courts merely interpreted the will of Parliament and common law precedent within the framework of the will of parliament. Statute law took precedence over previous decided cases. The highest court in the land, The House of Lords, was part of that process and decided cases on appeal that were considered to be of general public importance and general application beyond the parties to the case.

4. The Human Rights Act 1998 has had the effect of starting a process of change in the nature of the UK court system. This statute incorporated into UK law the European Convention on Human Rights which came into force on 4 November 1950. The full title is the "Convention for the Protection of Human Rights and Fundamental Freedom". The consequence is that the House of Lords is changing from being the final Court of Appeal to becoming a "Supreme Court."

The Preamble to the Statute of the Council of Europe says that contracting states reaffirm "their devotion to the spiritual and moral values which are the common heritage of their peoples and the true source of individual freedom, political liberty and the rule of law, principles which form the basis of all genuine democracy".

All Member States are expected to accede to the ECHR which as amended by Protocol 11 establishes the right of individuals to apply to the Court of Human Rights and of a fully "judicial" framework to enforce human rights. It is not sufficient for human rights to be the domestic prerogative of the individual European states because the experience of the second world war showed that the states could not be trusted to respect human rights.

\footnotetext{
"The uniqueness of these provisions lay in the fact that questions of human rights fell traditionally within the domestic jurisdiction of States, and were of concern to international law only if the interests of another state were affected, as for example by the treatment of its nationals. History had all convincingly demonstrated the inadequacy of those traditional concepts of international law and State sovereignty which made the protection of individuals the exclusive prerogative of the State of which they were nationals. Their rights may require protection, above all, against their own state - and the values of democratic government require a collective guarantee-for there are no boundaries to the denial of liberty. The creation of the Council of Europe and the adoption of the Convention on Human Rights are an
} 
acknowledgment that the protection of human rights is viewed as an indispensable element of European democracy.” (Jacobs)

"The ECHR is not based, as are most other treaties, on reciprocity and does not involve a mutual exchange of rights and obligations by the contracting parties. Its object is to set up an independent legal order for the protection of individuals." (Jacobs)

\section{INDEPENDENT ORDER FOR THE PROTECTION OF INDIVIDUALS}

The ECHR is a supra- national and independent order for the protection of individuals.

A supra national authority for this purpose is unattractive to those in the UK who argue for the full sovereignty of each nation state within Europe. It has profound constitutional and jurisprudential consequences. It is doubtful that these were foreseen, or are welcome, by the very same UK government which introduced the ECHR. It has been argued that such a supra- national independent order for the protection of individuals has been unnecessary in the case of the UK because the UK has a long history of individual rights and protection. A recent study into the effect of the ECHR on family court proceedings in the UK has tended to support that viewpoint (Fortin). A number of family and child law cases have been argued by reference to the ECHR and the UK. Courts have taken the view that ECHR arguments add little or nothing to the principles that are long established in the practice of those courts and that in effect human rights are fully protected by the long-established UK statute and common law.

Although the UK was one of the first signatories to the ECHR it was not until the Human Rights Act of 1998 that the ECHR was incorporated into the domestic law of the UK. If the UK implicitly assumed that its domestic law achieved all that was necessary for the full protection of human rights, then why incorporate the ECHR through the 1998 statute? Incorporation of the ECHR is a prerequisite for membership of the European Union; recent history, with the House of Lords overturning government administrative action with suspected terrorists, has been clearly unwelcome to the UK government, and has provoked ministerial comment about undue interference by the judiciary. The Human Rights Act 1998 incorporating the ECHR into national law is "an event of major constitutional significance"(Jacobs).

The practical effect is to give the UK courts the jurisdiction to declare acts of Parliament and/or government action pursuant to that legislation to be ultra vires. When deciding this the courts do not restrict themselves to an analysis of the wording of legislation and decided cases but: "Firstly, in determining whether there has been a violation of a convention right, a court or tribunal must take into account case law of the
Commission, Court of Human Rights, and the Committee of Ministers. In interpreting any primary or secondary legislation whenever enacted, the court or tribunal must "so far as it is possible to do so, read and give effect to that legislation in a way which is compatible with the Convention rights" (Jacobs).

\section{PRACTICAL CONSEQUENCES FOR THE UK}

One view is that there is no conflict between the UK practice of including non adjudicated allegations in a child worker's or teacher's "criminal record," and Article 6 of the ECHR. That view is supported by the fact that in England and Wales an appellate body called the Care Standards Tribunal was set up pursuant to the Protection of Children Act 1999. Persons that have been included on a list of proscribed people have a right of appeal to the Care Standards Tribunal. Whether this goes far enough to satisfy Article 6 of the ECHR is arguable, because by the time such a person becomes eligible to appear before the Tribunal he/she will already have suffered irreversible damage to their reputation and peace of mind.

\section{The Care Standards Tribunal}

The Care Standards Tribunal hears appeals from decisions made by:

(1) The Secretary of State for Education.

(2) The Commission for Social Care Inspection England and the National Assembly for Wales.

(3) The Commission for Healthcare Audit and Inspection and the National assembly for Wales.

(4) Decisions of the Chief Inspector of Schools in England and the National Assembly for Wales.

(5) Decisions of the General Social Care Council and the Care Council Wales.

For the purposes of this paper the appellate jurisdiction for (1) above is of major relevance.

The decisions of the Secretary of State for Education and Skills which can be appealed are:

(1) Inclusion of individuals' names on the list of those considered unsuitable to work with children (the POCA list). This function was transferred from the Department of Health.

(2) Restriction or prohibition from teaching, acting as proprietor of independent schools and employment in schools/further education institutions.

(3) Registration of independent schools.

\section{IS THE UK MOVING FURTHER AWAY FROM THE EU?}

As a result of the political furore referred to in the opening passage of this article the "Safeguarding Vulnerable Groups Bill" has been introduced in England 
and Wales. This Bill intends to merge all the existing disqualification lists. Controversially, it does not provide a satisfactory right of appeal. An administrative banning order is made. An Independent Barring Board can revue paper cases. There is no opportunity for a hearing. Rather than limiting the scope and effect of executive decisions, the power of the executive is increased with consequent increased vulnerability of child care workers and teachers to executive decision. A collision course with Article 6 ECHR has been set.

An appeal can be made to the Care Standards Tribunal but only on a point of law with the leave of the Care Standards Tribunal. This development is in effect a step further away from the principles of Article 6 ECHR. An amendment has been proposed to allow appeals on both fact and law.
The case of Leeds City Council v Price [2005] 1 WLR 1825 includes the view of the Court of Appeal that section 2 of the Human Rights Act 1998, which stipulates that the UK courts "take into account" the decisions of the European Court of Human Rights, does not mean that decisions of the European Court of Human Rights should take precedence over inconsistent decisions of the House of Lords. At the time of writing this case is currently before the House of Lords.

The development of supranational principles of law would appear to be encountering a set back at present.

\section{Graham Ritchie}

Solicitor; Director, Unit for the Law of Children and the Vulnerable,

Anglia Ruskin University 